\title{
A strategic plan for ACRL (First draft)
}

\author{
Prepared by the ACRL Strategic Planning Task Force
}

Susan Klingberg, Chair

\section{The first draft of a plan for ACRL's future.}

$\mathbf{I}$ n the Fall of 1984, the Task Force was appointed and charged with developing a strategic plan to guide the development of the Association between 1986 and 1990. The following draft will be reviewed and discussed at an open forum at the ALA Midwinter Meeting in January 1986 organized by the Task Force. The final plan is due at the 1986 Annual Conference. Your written comments are invited.

This first draft was developed according to a planning process approved by the ACRL Board of Directors and published in CURL News, September 1984 , pp.396-401. In addition to following a structured planning process, the work of the Task Force was guided by three premises: 1) planning would be based on the expressed needs of members; 2) planning would facilitate involvement of all ACRL units (committees, chapters, sections, etc.); and 3) division planning would be coordinated with the ALA planning process.

The first step in the process was an analysis of members' needs which drew on existing membership data as well as data from Sharon Rogers' President's Program on July 8, 1985, in which participants determined priorities for ACRL activities. Results were also considered from the President's questionnaire on priorities which was mailed to a random sample of ACRL members prior to the program.

Other elements in the planning process were a review of environmental factors (published in this issue), and the identification of opportunities, threats, strengths, and weaknesses relating to the Association. ACRL'S resources, policies, programs, and current strategies were also analyzed in a strategic audit.

In the development of this draft plan, the Activity Model for 1990 (C\&RL News, May 1982, pp.164-69) was a key resource. The Mission, Goals, and Subgoals below are revisions of Section III of that document. The term Goal is used here in the same sense as in the Activity Model: "qualitative statements which collectively describe the conditions existing when ACRL is fulfilling its Mission."

For each Subgoal below, the Task Force developed a number of Objectives. Objectives were defined as specific activities or ends which lead to fulfillment of ACRL Goals. They are generally time-limited and/or measurable. "Critical" Objectives are those Objectives which the Task Force identified as high priority. The priorities expressed by members through the questionnaire survey and the President's Program were carefully considered during the process.

In terms of the critical objectives, the next step for the Task Force will be to develop strategies and to target a specific year. A strategy is a means to achieve an Objective, as in the following example from Subgoal A under Goal II:

Objective: Publicize ACRL standards throughout the higher education community.

Strategy: Announce the availability of ACRL standards in the Chronicle of Higher Education. 
Once the strategic plan is completed and approved by the ACRL Board of Directors, it will be referred to the Planning Committee to implement. The Planning Committee will also assume responsibility for maintaining the planning process including reviewing, evaluating, and updating the plan. The evaluation component includes the periodic assessment of member needs.

To sum up, the work of the Task Force will result in a written strategic plan to guide the development of the Association until 1990. The Task Force has also implemented a structured planning process which will provide a framework for all Association planning activities. This process will facilitate the work of the ACRL Budget and Finance Committee by determining priorities which can be used to guide the allocation of resources. The use of a structured planning process will also help the Division to coordinate its planning efforts with those of ALA.

\section{Mission Statement}

The mission of the Association of College and Research Libraries (ACRL) is to foster the profession of academic and research librarianship and to enhance the ability of academic and research libraries to serve effectively the library and information needs of current and potential library users.

\section{Goal I}

To contribute to the total professional development of academic and research librarians.

\section{Subgoals}

A. To sponsor and encourage opportunities for academic and research librarians to update existing competencies, learn requisite new skills, and gain awareness of the state of the art.

B. To afford a sense of professional identity and peer reinforcement to academic and research librarians.

C. To provdie career counseling and placement information regarding academic and research librarianship.

D. To seek new members and maintain present members.

\section{Critical Objectives}

1. Lower the cost to participate in ACRL profes-

Editor's note: The Strategic Planning Task Force consists of Susan Klingberg (chair), California State University, Sacramento; David Bishop, University of Georgia; Sharon Hogan, ACRL President, 1985-86, Louisiana State University; Don Riggs, Arizona State University; Keith Russell, National Agricultural Library, Beltsville, Md.; Carla Stoffle, University of Michigan; and JoAn Segal, ACRL Executive Director. sional development activities.

2. Expand opportunities for academic and research librarians to participate in professional development activities.

3. Strive for a net increase in ACRL membership.

\section{Goal II}

To improve service capabilities of academic and research librarians.

\section{Subgoals}

A. To provide appropriate standards and guidelines.

B. To provide advisory services related to academic and research libraries and librarianship.

C. To identify and explore problems and issues relevant to academic and research libraries and to take action where appropriate and possible.

D. To encourage innovation in academic and research library operations and service.

E. To enhance collection development in academic and research libraries.

\section{Critical Objectives}

1. Develop guidelines for academic library performance evaluation and output measures.

2. Publicize ACRL standards throughout the higher education community.

3. Increase understanding of the accreditation process.

4. Ensure that essential academic library statistics are collected and disseminated in a timely fashion.

5. Publicize examples of innovative activities.

\section{Goal III}

To promote and speak for the interests of academic and research librarianship.

\section{Subgoals}

A. To enhance awareness of the role of academic and research libraries among non-library professionals and organizations (accrediting bodies, higher education associations, scholarly and professional associations, etc.) and to develop effective working relationships with them.

B. To monitor and speak out on government and private sector activities likely to affect academic and research librarianship, including legislation and fiscal and political support at all levels.

C. To support and participate in the recruitment of promising persons to the field of academic and research librarianship.

D. To monitor and help shape library education programs in accord with the needs of academic and research librarianship.

\section{Critical Objectives}

1. Provide opportunities in a variety of settings for academic librarians to interact with other pro- 
fessionals in the academic community.

2. Establish mechanisms for identifying and responding to bodies created to study issues of importance to academic libraries.

3 . Encourage and facilitate effective membership response to government and private sector activities, including appropriate legislation.

\section{Goal IV}

To promote study, research, and publication relevant to academic and research librarianship.

\section{Subgoals}

A. To promote awareness of the need for research, identify study and research topics, and encourage improvement in research skills.

B. To participate in research projects, report works in progress, and disseminate research results.

C. To support research relating to academic and research libraries.

D. To sponsor a strong publishing program that will advance the professional knowledge and understanding of academic librarians.

\section{Critical Objectives}

1. Develop and implement a research agenda for academic libraries.

2. Create appropriate mechanisms for identifying, collecting, storing, and disseminating research of interest to academic and research librarians.

3. Undertake a comprehensive review of the ACRL publications program to ensure that the objectives are being met.

\section{External factors analysis statement}

The first draft of this statement was prepared by the ACRL Planning Committee. It was then revised by the ACRL Strategic Planning Task Force and incorporated into their planning process, which will culminate in a written five-year plan for the Association. The statement is essentially an updating of the environmental considerations portion of the original ACRL activity model (C\&RL News, May 1982, p.164).

A. Economic Considerations.

1. The concept of information as a commodity will increasingly influence decisions relating to libraries.

2. Steady-state or declining purchase power will be available to academic/research libraries.

3. Costs of computing hardware will decline; the costs of software and telecommunications will increase.

4. Competition between libraries and other organizations, both on campus and in the for-profit sector, will increase.

5 . Libraries will be expected to increase productivity.

\section{B. Political Considerations.}

1. Information will be an increasingly important strategic factor in domestic and international markets and in world politics.

2. Conflict will escalate among government, business and academia over the ownership, value, and control of information.

3. Federal government attitude toward academic/research libraries will be increasingly laissez-faire.

4. State governments will increase efforts to centralize authority/control over tax-supported higher education, including academic libraries.

5. The distribution of computing power will di- minish the political impact of national consortia.

6. Local, state, and regional computer-based networks will continue to develop.

7. There will be continuing international pressure for bibliographical standardization.

C. Social Considerations.

1. Equality of opportunity for women and minorities will continue to be an elusive goal.

2. Illiteracy will continue to be a problem in spite of the efforts of schools, libraries, and the educational reform movement.

3. Well-organized political and religious groups will continue to mount challenges to intellectual freedom.

4. The development of massive databases may threaten individual privacy.

5. Academy-based research activity will advance slowly.

6. The demographic profile and educational needs/expectations of college students will continue to change.

7. The use of non-print and micro-based materials in research and college teaching will increase.

8 . Society will continue to press for dollar accountability.

(continued on next page)

\section{Strategic planning forum}

The ACRL Strategic Planning Task Force will be holding an open forum during the Midwinter Meeting on January 20 from 4:30 to 6:30 p.m. The forum is being held to allow ACRL members and other interested parties to respond to the first draft of the ACRL Strategic Plan, published in this issue. 